\title{
The Role of Emotional Empathy, Occupational Role Stress and Job Satisfaction among Teachers of Special and Normal Schools
}

\author{
${ }^{1}$ Dr. Nazia Iqbal, ${ }^{2}$ Noureen Kazim
}

\begin{abstract}
This study investigated the Emotional Empathy, Occupational Role Stress and Job Satisfaction among Teachers of average and Special education institutes. The objectives of this study included to explore; predictive relationship between emotional empathy, occupational role stress and job satisfaction among teachers of special education and normal schools, gender difference in teachers of special education and normal children schools on emotional empathy and difference in job satisfaction of teachers of special education and normal children schools in the context of Pakistan. In present study three instruments were used; Emotional empathy scale (Caruso \& Mayer, 1998), occupational role stress scale (Pareek, 1993) and Job satisfaction scale (Macdonald \& MacIntyre, 1991). These were administered on the sample of 150 teachers along with informed consent. To achieve the objectives of the study hypotheses were formulated and tested by using correlation and regression analysis. Hypotheses were strongly supported; the results showed that normal school teachers were more empathetic as compared to the special school teachers. The results also supported the hypothesis that occupational role stress had negative correlation with job satisfaction. Special education teachers showed higher level of occupational role stress and low job satisfaction as compared to normal school teachers.
\end{abstract}

Keywords: Emotional empathy, Occupational role stress, Job satisfaction

\section{Introduction}

In educational organizations, employees are hardworking, committed and providing favorable working conditions. They utilize their talent, skills and will grease the wheels of organizational machinery. In Special Education Department, teachers play outstanding role in the development of student's behavior, attitude, skills, and the knowledge necessary for living independent and productive life as compared to other members of this organization. Research has shown that teachers who are empathic are highly moral individuals and they attach themselves mentally and emotionally to the students to generate similar responses in return. Through their personal interactions they invoke morality in

\footnotetext{
${ }^{1}$ Assistant Professor, Department of Psychology, IIU Email: nazia.iqbal@iiu.edu.pk

${ }^{2}$ Assistant Professor, Department of Psychology, IIU
} 
their students and colleagues (Cooper, 2002).

"Empathy is an important component of social cognition that contributes to one's ability to understand and respond adaptively to other's emotions, succeed in emotional communication, and promote pro social behavior". The study of empathy is captivating because "the tendency of humans to experience the emotional states of others" probably has massive implications for social interaction (Rogers, 1975).

Job satisfaction is a condition that refers to make a person feel satisfied with their job and many aspects of job like psychological, physiological and environmental aspects. Job satisfaction can be defined as "the positive and negative feelings and attitudes employees hold about a job" (Schultz \& Schultz, 2010). Tettand Meyer (1993) described the driving factors of job satisfaction into two broad aspects: external aspects (organizational, social and cultural characteristics) and internal aspects (personality, affective and emotional characteristic) (Hoppock, 1977). It may be argued that in special education department, low job satisfaction of teachers could be a reason of teachers' resignation - this assumption will be tested. Job satisfaction can be assessed according to a worker's expectations, value and reward (Evans, 1998); and can be established by differentiating between the person's expectations and the personal fulfillment about job (Evans, 1997).

Lewis (1999) conducted a research and compared the levels of satisfaction and dissatisfaction among special and general school teachers. Teachers of special education were found to be more dissatisfied from within and from outside the class room. The difficulties were particularly common in younger, less experienced special education teachers. It is argued that emotional empathy affects job satisfaction. Emotional awareness can help in the regulation of negative feelings and if the individual will have a better performance in their job; then it will set the foundation of job satisfaction and it seems that employees with high emotional empathy will be more satisfied with their jobs (Harris et al., 2008).

According to Kantas (2001) teacher stress may be defined as 'the experience of unpleasant emotions like anger, anxiety, tension, frustration or depression, resulting from working conditions'. The factors that impact teachers' job satisfaction can be divided into three domains: micro level (teacher background factors); meso level (school-level factors); and macro level (factors associated with society and the education system). The abnormal reaction to the threatening environmental elements is stress. Stress can be divided into two ways: eustress and distress. Eustress is named as positive stress and often associated as moderate and low stress levels while distress is the high level of 
stress experienced by individuals (Akomolafe \& Ogunmakin, 2014). Teachers who experience eustress would be able to meet job demands, this could contribute to the increased quality of work life.

Decreased quality of work life is the end result in teachers who experience distress and may not be able to fulfill job demands (Newell, 2002). Teachers' stress is a kind of work stress in the course of discharging teachers' responsibilities. As a teacher, different working aspects may lead to tension, frustration, anger and depression (Kyriacou, 1987).

Special education teachers' choose their profession to produce changes in the student's lives with special needs and at the same time they fulfill their own goals and self-worth (Pranjić \& Grbović, 2011). At the same time, research findings provide information about the negative aspects of special education teaching. The negative factors include poor school climate, role confusion, and increased level of stress and decreased levels of job satisfaction (Gersten et. al, 2001). Job stressors were found to be predictive of job dissatisfaction (Cooper, Rout \& Faragher, 1989). Ismail et al. (2009) determined that physiological stress level has increased job satisfaction and psychological stress level did not decrease job satisfaction (Akomolafe \& Ogunmakin, 2014). Poor working conditions also induce stress that has strong influence on the teachers' job satisfaction (Liu \& Rawsa, 2008). Rationale of the present research is to explore the relationship between emotional empathy, occupational role stress and job satisfaction among teachers of special education institutions. Aim of the present research is to explore this phenomenon in Pakistani population with the help of primitive, reliable, and valid instruments.

\subsection{Objectives of the study}

The purpose of the present study was;

1 To explore the predictive relationship between emotional empathy, occupational role stress and job satisfaction among teachers of special education and normal schools.

2 To explore difference in the emotional empathy among special and general school teachers.

3 To explore difference in job satisfaction among teachers of special education and general schools.

\subsection{Hypothesis}

1 There is a positive relationship between emotional empathy and job satisfaction among teachers of special education.

2 There is a negative relationship between occupational role stress and job satisfaction among teachers of special education and mainstream schools. 
3 Teachers of special educational institutes have high level of emotional empathy and occupational role stress as compared to teachers of mainstream schools.

4 There is a higher level of occupational role stress in teachers of special education institutes than teachers of mainstream schools.

5 There will be significantly lower level of job satisfaction in teachers of special education institutes than teachers of mainstream schools.

\subsection{Operational Definition of Variables}

\section{Emotional Empathy}

Empathy means to feel what the other feels. It is the unique capacity of the human beings to recognize emotions of others (Goleman, 1995).

\section{Occupational Role Stress}

Occupational role stress is defined as condition arising from the interaction of people and their jobs, and characterized by changes within the people that force them to deviate from their normal functions (Bechr \& Newman, 1978).

\section{Job Satisfaction}

Macdonald and MacIntyre (1997), defined job satisfaction as "an individual's positive affective reaction of the target environment as a result of the individual's appraisal of the extent to which his or her needs are fulfilled by the environment".

\section{Literature Review}

A review of literature indicate that there is a positive relationship between emotional empathy and job satisfaction (Mousavi et al., 2012) and occupational role stress and job satisfaction (Billingsley \& Cross 1992). Individuals with empathy have ability to spontaneously and naturally perceive other person's thought and feelings. Empathy affects person's job satisfaction and has a significant influence on the employee behavior.

According to Rogers (1975), the presence of high empathy level among employees reduces stress related to job and therefore it increases the job satisfaction. An appraisal of previous researches indicated that empathy is positively associated with job satisfaction. It is the intension of the present study to establish if there is a positive association between job satisfaction and emotional empathy among teachers of special education. Similarly, teachers who experience distress are dissatisfied with their jobs. There is a limited research evidence about the teachers of special education institutes, therefore present study attempts to find the impact of empathy and occupational role stress on job 
satisfaction. The study has also compared the variables among teacher of schools for normal children and special children.

\subsection{Research Design}

\section{Research Methodology}

The research was descriptive in nature and survey technique was used to investigate the Emotional Empathy, Occupational Role Stress and Job Satisfaction among Teachers of average and Special education institutes.

\subsection{Population and Sample}

The participants of the study included teachers $(N=150)$ belonging to special $(n=75)$ and normal children $(n=75)$ government schools of Rawalpindi and Islamabad during the year 2015. The participants of the present study comprised of full time permanent teachers of government schools for special and general school education. Purposive sampling technique was used to select sample for present study.

\subsection{Instruments}

Emotional Empathy Scale (EES): Multidimensional Emotional Empathy Scale was developed by Caruso and Mayer (1998) at University of New Hampshire. The scale consists of 30 items and is scored on five points from "strongly agree" to "strongly disagree". The reliability estimate of alpha coefficient $(\alpha=.85)$ for EES scale.

Occupational Role Stress Scale: Occupational Role Stress Scale developed by Pareek (1993) was used. It has 50 items. It is a five point Likert scale 1-5. It measures 10 different role stressors. This scale has accepted reliability estimate of alpha coefficient .93. The scale and their items measuring the subscale are given below:
1. Inter role distance
2. Role stagnation
3. Role expectation
4. Role isolation
5. Role erosion
6. Self-role
7. Role over load
8. Resource inadequacy
9. Personal inadequacy
10. Role ambiguity

Generic Job Satisfaction Scale: For the present study the generic job satisfaction scale developed by Macdonald and MacIntyre (1991) was used as a measure of job satisfaction. The scale consists of 10 items and is scored on five points likert scale. The internal consistency reliabilities of the generic scales range from 0.80 to 0.88 , as determined by corrected split half correlations. The 
scales are highly co-related with other measures of satisfaction (average $=.70$ ).

\subsection{Data Collection}

By using the aforementioned standardized scales, data were collected through personal visits of the researcher to the sampled institutions.

Table 1

\section{Findings}

Demographics of participants $(\mathrm{N}=150)$

\section{Grouping variables}

\section{School system}

Special education

General education

\section{Education}

Graduates and below

Masters and above

\section{Marital Status}

Married

Unmarried

\section{Age}

Young

Old
64

86

75

75

80

70

For the present study 150 participants were selected. These participants were classified on the basis of school system as teachers for special education ( $n$ $=75)$ and general education $(n=75)$. Teachers were also classified as graduate and below $(n=64)$ and masters and above $(n=86) .73$ teachers of the total sample were married while 77 were unmarried. Participants were of two age groups as young $(n=80)$ and old age $(n=70)$

Table 2

Alpha Coefficients, Descriptive Statistics and Range of multidimensional scale of emotional empathy, occupational role stress and job satisfaction scale $(\mathrm{N}=150)$ 


\begin{tabular}{|c|c|c|c|c|c|c|c|c|}
\hline \multirow[t]{2}{*}{ Scales } & \multirow[t]{2}{*}{$N$} & \multirow[t]{2}{*}{$A$} & \multirow[t]{2}{*}{$M$} & \multirow[t]{2}{*}{$S D$} & \multirow[t]{2}{*}{ Skewness } & \multirow[t]{2}{*}{ Kurtosis } & \multicolumn{2}{|c|}{ Range } \\
\hline & & & & & & & Potential & Actual \\
\hline Emotional empathy & 30 & .85 & 85 & 44.24 & -.015 & -1.06 & 42 & 104 \\
\hline $\begin{array}{l}\text { Occupational role } \\
\text { stress }\end{array}$ & 50 & .85 & 104 & 69.25 & -.027 & -1.78 & 141 & 162 \\
\hline Job satisfaction & 10 & .88 & 49 & 11.10 & -.098 & -1.77 & 18 & 33 \\
\hline
\end{tabular}

Table 2 indicates psychometric properties of multi-dimensional emotional empathy scale, occupational role stress scale and job satisfaction scale. The mean scores for emotional empathy is $85.48(\mathrm{SD}=44.25)$, for occupational role stress mean is $104.7(\mathrm{SD}=69.25)$ and for job satisfaction scale mean is 49 $(\mathrm{SD}=11.10)$. Reliability estimate is found by Cronbach's alpha. Coefficient alpha for multi - dimensional scale of emotional empathy is .855 for occupational role stress is .851 and for job satisfaction scale is .884

Table 3

Relationship of Job Satisfaction with Occupational Role Stress and Emotional Empathy $(\mathrm{N}=150)$

\begin{tabular}{lc}
\hline Scales & Job satisfaction \\
\hline Emotional empathy & $.937^{* * *}$ \\
occupational role stress & $-.932^{* * *}$ \\
\hline
\end{tabular}

$$
* * * p<.001
$$

Table 3 shows correlation among emotional empathy, occupational role stress and job satisfaction. Results indicate significant positive correlation between emotional empathy and job satisfaction $(p<.001)$ and significant negative correlation between occupational role stress and job satisfaction $(p<$ $.001)$. 
Table 4

Hierarchical Multiple Regression Analysis on Emotional Empathy, Occupational Role Stress and Job Satisfaction $(\mathrm{N}=150)$

\begin{tabular}{lrcc}
\hline Predictors & \multicolumn{3}{c}{ Job satisfaction } \\
\hline Step I & $\mathrm{B}$ & $S E$ & $\mathrm{~B}$ \\
Constant & & & \\
Emotional empathy & 12.60 & .690 & \\
Step II & .235 & .007 & $.937^{* * * *}$ \\
Constant & & & \\
Emotional empathy & 19.024 & 7.801 & \\
Occupational role stress & .193 & .051 & $.770^{* * *}$ \\
\hline
\end{tabular}

For step $1: \mathrm{R}^{2}=.879 ; \mathrm{F}=1073.82 * * *$

For step $2: \mathrm{R}^{2}=.879 ; \mathrm{F}=536.102 * * * ; \Delta \mathrm{R}^{2}=.012 ; \Delta \mathrm{F}=14.02$

Table 4 reveals significant predictive relationships between emotional empathy and job satisfaction. The first model in above Table is suggesting that emotional empathy is significant predictor of job satisfaction. The values of $R^{2}$ (.879 for emotional empathy) indicate that the above mentioned variable can predict $87 \%$ of job satisfaction. As the B values are positive which are indicative of the fact that the prediction is in the same direction. In other words higher the scores on emotional empathy will predict more job satisfaction among school teachers. The prediction is significant as $[(F(1,148)=1073.829$ and $p<.05)]$ for emotional empathy.

The second model include occupational role stress as other predictor of job satisfaction, the values of $R^{2}(.879)$ indicate that occupational role stress can predict $87 \%$ of job satisfaction $[F(2,147)=536.12$ and $p<.05)]$. As the $\mathrm{B}$ values are negative which are indicative of the fact that the prediction is in the opposite direction. In other words higher the scores on emotional empathy will predict less job satisfaction among school teachers. The prediction is significant as $[(F$ $(1,148)=1073.829$ and $p<.05)]$ for occupational role stress. 
Table 5

Mean differences of emotional empathy, occupational role stress and job satisfaction between teachers of special and general education $(\mathrm{N}=150)$

\begin{tabular}{|c|c|c|c|c|c|c|c|c|}
\hline \multirow[t]{3}{*}{ Scales } & \multicolumn{2}{|c|}{$\begin{array}{l}\text { Teachers of schools } \\
\text { for general education }\end{array}$} & \multicolumn{5}{|c|}{ Teachers of schools for special education } & \\
\hline & \multicolumn{2}{|c|}{$(n=75)$} & \multicolumn{2}{|l|}{$(n=75)$} & \multicolumn{3}{|c|}{$95 \% \mathrm{CI}$} & \\
\hline & $M$ & $S D$ & $M$ & $S D$ & $t(148)$ & $P$ & $L L$ & $U L$ \\
\hline $\begin{array}{l}\text { Emotional } \\
\text { empathy }\end{array}$ & 129 & 3.16 & 43 & 14.84 & 48.19 & .000 & 82.03 & 89.04 \\
\hline $\begin{array}{l}\text { Occupational role } \\
\text { stress }\end{array}$ & 36.02 & 10.46 & 169.85 & 21.65 & 47.77 & .000 & -139.3 & -128.2 \\
\hline Job satisfaction & 43.31 & 2.44 & 22.66 & 5.05 & 31.56 & .000 & 19.35 & 21.92 \\
\hline
\end{tabular}

Table 5 indicates difference in emotional empathy, occupational role stress and job satisfaction among teachers of special education school and general education school. Result shows that there is a significant difference $(\mathrm{p}<$ .05 ) in emotional empathy, occupational role stress and job satisfaction among teachers of schools for special education and general education.

Table 6

Mean difference of emotional empathy, occupational role stress and job satisfaction among teachers of lower and upper age group $(\mathrm{N}=150)$

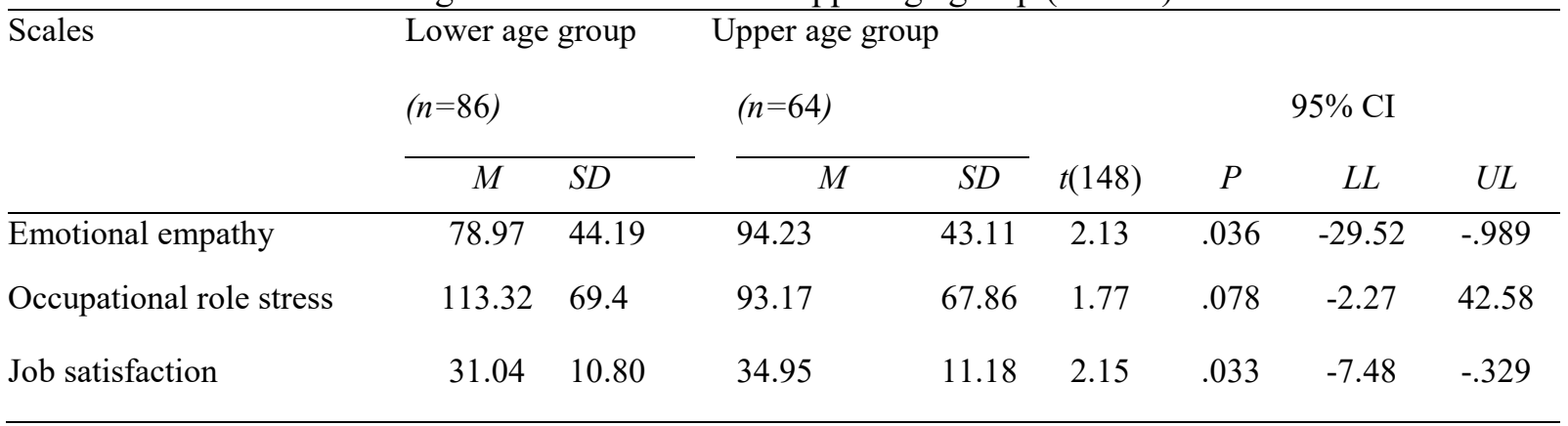

Table 6 indicates mean difference in emotional empathy, occupational role stress and job among teachers of upper and lower age groups. Result shows that there is a significant difference $(p<.05)$ in emotional empathy and job satisfaction among teachers of upper and lower age. Results indicate that there is no significant difference $(p>.05)$ in occupational role stress among teachers of 
upper and lower age group.

Table 7

Mean difference of emotional empathy, occupational role stress and job satisfaction among married and unmarried teachers $(\mathrm{N}=150)$

\begin{tabular}{lccccccccc}
\hline Scales & \multicolumn{1}{l}{ Unmarried } & Married & & & & & \\
\hline & $(n=73)$ & & $(n=77)$ & & & & $95 \% \mathrm{CI}$ & \\
& $M$ & $S D$ & $M$ & $S D$ & $t(148)$ & $P$ & $L L$ & $U L$ \\
Emotional empathy & 85.91 & 44.15 & 85.07 & 44.61 & .116 & .908 & -13.49 & 15.16 \\
Occupational role stress & 104.5 & 70.90 & 104.93 & 68.12 & .038 & .970 & -22.86 & 22.00 \\
& & & & & & & & \\
Job satisfaction & 32.52 & 11.37 & 32.89 & 10.89 & .206 & .837 & -3.97 & 3.21 \\
\hline
\end{tabular}

Table 7 indicates difference in emotional empathy, occupational role stress and job among married and unmarried teachers. Result shows that there is a no significant difference $(p>.05)$ in job satisfaction, occupational role stress and emotional empathy among married and unmarried teachers.

\section{Discussion}

The present research is conducted to explore the phenomenon of emotional empathy, occupational role stress and job satisfaction on a sample of special education and general education school teachers. Further the study is focused to find out the relationship among emotional empathy, occupational role stress and job satisfaction among school teachers. Another objective of the present research is to find out relationship among job satisfaction, emotional empathy related and occupational role stress. Further the relationship of demographic variables such as age, marital status of teachers on emotional empathy and job satisfaction was also explored.

First of all, psychometric properties of the emotional empathy occupational role stress and job satisfaction were disclosed on the sample of school teachers of Rawalpindi and Islamabad. Significant reliability was found for all study variables. It was revealed that emotional empathy had significant high correlation with job satisfaction and that was in accordance with hypothesis. The results also supported the hypothesis that occupational role stress had negative correlation with job satisfaction. Reduction of stress may increase job satisfaction. Muhammad et al. (2011) also revealed that there is a negative relationship between job stress and job satisfaction. Regression analysis showed that occupational role stress had a role as a moderator in the impact of emotional 
empathy on job satisfaction. Decreasing the stress may lead to increase in job satisfaction.

The results supported the hypothesis that special education teacher has higher level of occupational role stress and low job satisfaction as compared to normal school teachers. The main cause of extreme stress was low level of regular supervision concerning work, low level of social support and finally work was mentally and physically demanding. The special education teachers feel dissatisfaction with present work, life and health. For female special school teachers, a balanced social role orientation was associated with higher level of job satisfaction and lower levels of satisfaction and higher levels of distress. Fish (2009) reported similar results. The findings were also supported byStrunk and Robinson (2006) and Banks \&Necco (1990).

It was further hypothesized that older teachers would be more empathic as compared to the young teachers. The results were in line with the research done by Knowles (1980) who found thatolder teachers had higher self-esteem and their needs were met frequently so they felt more empathic as compared to the young teachers. According to Dunham (1992) the teachers who felt more satisfied were more empathic because they had chosen their profession in more determined and aware way. Older teachers indicated that their self-esteem was met more frequently so they are more empathic and satisfied (Knowles, 1980).

There was no significant difference in the normal and special school teachers in terms of marital status regarding the variables under consideration. This was in contradiction with the hypothesis. AbuAlRab (2004) found that marital status was not always a determinant ant that in some cases those who are happy in their married life get support from their spouses and their professional life is successful too. This result was also supported by a study conducted by Pervaz and Hanif (2003) who found that there was no significant difference among married and unmarried teachers regarding job stress and job satisfaction.

\section{Conclusions}

Results of the study concluded that:

1. Special education teacher has higher level of occupational role stress and low job satisfaction as compared to normal school teachers

2.Older teachers were more empathic as compared to the young teachers

3. There was no significant difference in the normal and special school teachers in terms of marital status regarding the variables under consideration.

\section{Recommendations}

Educational programs should be introduced on electronic media like TV Talk shows to increase the importance and problems related to teaching 
profession in Pakistan. There should be programs to develop professional training and to increase interest level among new teachers. Working environment play an important role in any job field so, teachers should be provided supportive and collaborative environment to dissolve their problems. Workshops seem to be effective for teachers of both average and special institutes for their mental health like stress management. Workshop of emotional intelligence may be organized to enhance their emotional empathy.

\section{References}

AbuAlRub, R. F. (2004). Job stress, job performance and social support among hospital nurses. Journal of Nursing Scholarship. 36(1), 7378.

Akomolafe, M. J. \& Ogunmakin, A.O. (2014). Job Satisfaction among Secondary School Teachers: Emotional Intelligence, Occupational Stress and Self-Efficacy as Predictors. Journal of Educational and Social Research, 4(3).

Bank, S. R. \& Necco, E.G. (1990).The effects of special education category and type of training on job burnout in special education teachers. Teachers Education and Special Education, 13(3-4), 187191.

Beehr, T.A., \& Newman, J.E. (1978). Job stress, employees health \& organizational effectiveness: A Facet Analysis of Model \& Literature Review. Personal Psychology, 31(4), 665-669.

Billingsley, B. S., \& Cross, L. H. (1992). Predictors of commitment, job satisfaction, and intent to stay in teaching: A comparison of general and special educators, Journal of Special Education, 25(4), 453-471.

Caruso, D.R., \& Mayer, J. D. (1998). A Measure of Emotional empathy for Adolescents \& adults (Unpublished Manuscript), University of New Hempshire, Durnham.

Cooper, B. (2002) 'Teachers as Moral Models? The Role of Empathy in Teacher/Pupil Relationships' (unpublished PhD thesis), Leeds Metropolitan University. 
Cooper, C.L., Rout, U.,\& Faragher, B.(1989). Mental health, job satisfaction, and job stress among general practitioners. $B M J$, 298(6670), 366-370.

Dunham, J. (1992). Stress in Teaching ( $2^{\text {nd }}$ ed.). New York: Routledge.

Evans, L. (1997). Understanding teacher morale and job satisfaction.Teaching and Teacher Education, 13(8), 831-845. doi:10.1016/s0742-051x(97)00027-9

Evans, L. (1998). The Effects of Senior Management Teams on Teacher Morale and Job Satisfaction. Educational Management \& Administration, 26(4), 417-428. doi:10.1177/0263211x98264007

Fish, W. W. (2009). Special education: A Career of Choice. Remedial Special Education, 31(5), 400-407.

Gersten, R., Keating, T., Yovanoff, P.,\& Hrniss, M. (2001). Working in special education: factors that enhance special educators' intend to stay. Except child, 67(4): 554- 567.

Goleman, D. (1995). Emotional Intelligence. Newyork: Bantam Books.

Harris, S.F., Prater, M., Dyches, T., \& Allen Heath, M. (2008). Job Stress of School-Based Speech-Language Pathologists. Communication Disorders Quarterly, 30(2), 103-111. doi: $10.1177 / 1525740108323856$

Hoppock, R. (1977). Job satisfaction (1st ed.). New York: Arno Press.

Ismail, A., Yao, A.,\& Yunus, N. (2009). Relationship between occupational stress and job satisfaction: An Empirical Study in Malaysia. The Romanian Economic Journal, 7(34), 3-29.

Kantas, A. (2001), Factors of stress and occupational burnout of teachers, In V. E. Triliva. \& B. Kaie. (Eds.), Stress, Anxiety and Intervention (pp. 217-29). Ellinika, Athens: Grammata.

Knowles, B.S. (1980).Psychosocial correlates of teacher burnout (Unpublished Doctoral dissertation). West Virginia University.

Kyriacou, C. (1987). Teacher stress and burnout: An International Review. 
Educational Research, 29, 146-52.

Lewis, R. (1999), Teachers coping with the stress of classroom discipline, Social Psychology of Education, 3, 155-171.

Liu, X. S., \& Ramsey, J. (2008). Teachers' job satisfaction: Analyses of the Teacher Follow-Up Survey in the United States for 2000-2001. Teaching and Teacher Education, 24, 1173-1184.

Macdonalds, S., \& Maclntyre, P. D. (1997). The Generic Job Satisfaction Scale: Scale Development \& its Correlation. Employee Assistance Quarterly, 13(2), 1-16.

Mousavi, H., Yarmohammadi, S., BaniNosrat, A., Tarasi, Z. (2012). The relationship between emotional intelligence and job satisfaction of physical education teachers.Annuals of Biological Research, 3(2), 780-788.

Muhammad, M., Sabtain, F., Saima, N., \&Zubair, A. (2011). The impact of job stress on employee job satisfaction: A study on telecommunication sector of Pakistan. Journal of Business Studies Quarterly, 2(3), 50-56.

Newell, S. (2002).Creating the healthy organization: Well-being, diversity \& ethics at Work. London: Thomson Learning.

Pareek, U. (1993). Organizational Role Stress Scale. Ahmadabad: Naveen Publications.

Pervaz, S. \& Hanif, R. (2003). Levels and sources of work stress among women school teachers. Pakistan Journal of Psychological Research, 18(3-4), 97-108.

Pranjić, N. \& Grbović, M. (2011). Common factors related to the chronic occupational distress among special education teaching staff in Montenegro. International Journal of Peace and Development Studies. 2(4), 110-118.

Rogers, C. R. (1975). Empathic: An Unappreciated Way of Being. The Counselling Psychologist, 5 (2), 2-9.

Schultz, D.P. \& Schultz, S.E. (2010). Theories of Personality Psychology 
( $8^{\text {th }}$ ed.). Los Angeles: Tarcher.

Strunk, K. O. \& Robinson, J.P. (2006). Oh, wants' you stay: A multilevel analysis of the difficulties in retaining qualified teachers. Peabody Journal of Education, 81(4): 65-94.

Tett, R. P. \& Meyer, J. P. (1993). Job satisfaction, organizational commitment, turn over: path analysis based on Meta analytic finding. Personnel Psychology, 46(2), 259- 293. 